\title{
FORMULATION OF CONCRETE BASED ON PLANT MATERIALS (CASE OF RICINODENDRON HEUDELOTII: AKPI): OPTIMIZATION OF THE PROPORTION OF SHELLS
}

\author{
MAMERY ADAMA SERIFOU ${ }^{1}$, SOULEYMANE OUATTARA ${ }^{1}$, BRAHIMAN \\ TRAORE $^{* 1}$, CONAND HONORE KOUAKOU ${ }^{1}$, EDJIKEME EMERUWA ${ }^{1}$ \\ ${ }^{1}$ Laboratory of Geomaterials and Housing Technology, UFR-STRM, Félix Houphouët \\ Boigny Cocody- Abidjan University, Ivory Coast
}

\begin{abstract}
The aims of this work is to study the influence of the partial substitution of natural aggregates by the nut shells of Ricinodendron heudelotii known as AKPI, on the physical-mechanical properties of concrete. The substitution rates made are 5\%, 10\% and $15 \%$. Test results indicate that the presence of Akpi nut shells (ANS) causes increased porosity and reduced compressive strength of concrete. Increasing of porosity and decreasing of strength become important when the quantity of shell increases in concrete. However, the kinetics of hardening at a young age of the concrete is improved from $1 \%$ to $7 \%$.
\end{abstract}

Keywords: AKPI nutshell, partial substitution, physico-mechanical tests, light concrete

\section{INTRODUCTION}

The environmental aspect is today a major issue in the construction field. It becomes necessary not only to preserve the environment and non-renewable resources, but also to carry out works in an ecological way. The use of agricultural waste (palm nut shells, coconut shells, etc.) as aggregates in concrete is an alternative to the problem of depletion of natural resources. In addition to being recycling, this practice has the advantage of reducing production costs [1]. Thus, this work aims to study the influence of partial substitution of gravels by AKPI nut shells (CNA) on the physico-mechanical properties of concrete. The interest of these hulls lies at two levels: the growth in the consumption of its kernel, hence the large production of hulls which constitutes unused waste and their characteristics (dimensional homogeneity and low absorption rate).

\section{METHODOLOGY}

\subsection{Raw materials}

During this study different raw materials were used. These are aggregates, water, Akpi nut shells (Figure 1) and cement. The cement is Portland CPJ cement produced by LafargeHolcim-CI. The mixing water is drinkable water, from the national distribution network.

The ANS are used after a process consisting of different stages: decomposition of the fruit after two weeks, boiling of the seeds obtained for 8 to 24 hours and crushing of the nucleus. Once obtained, the hulls are soaked in water for 8 hours in order, to saturate them with water before use. For this study, the ANS come from the locality of AKOUPE in the South-east of Côte d'Ivoire, where the local population makes significant use of them.

\footnotetext{
* Corresponding author, email: traorebrahiman@yahoo.fr

(C) 2020 Alma Mater Publishing House
} 


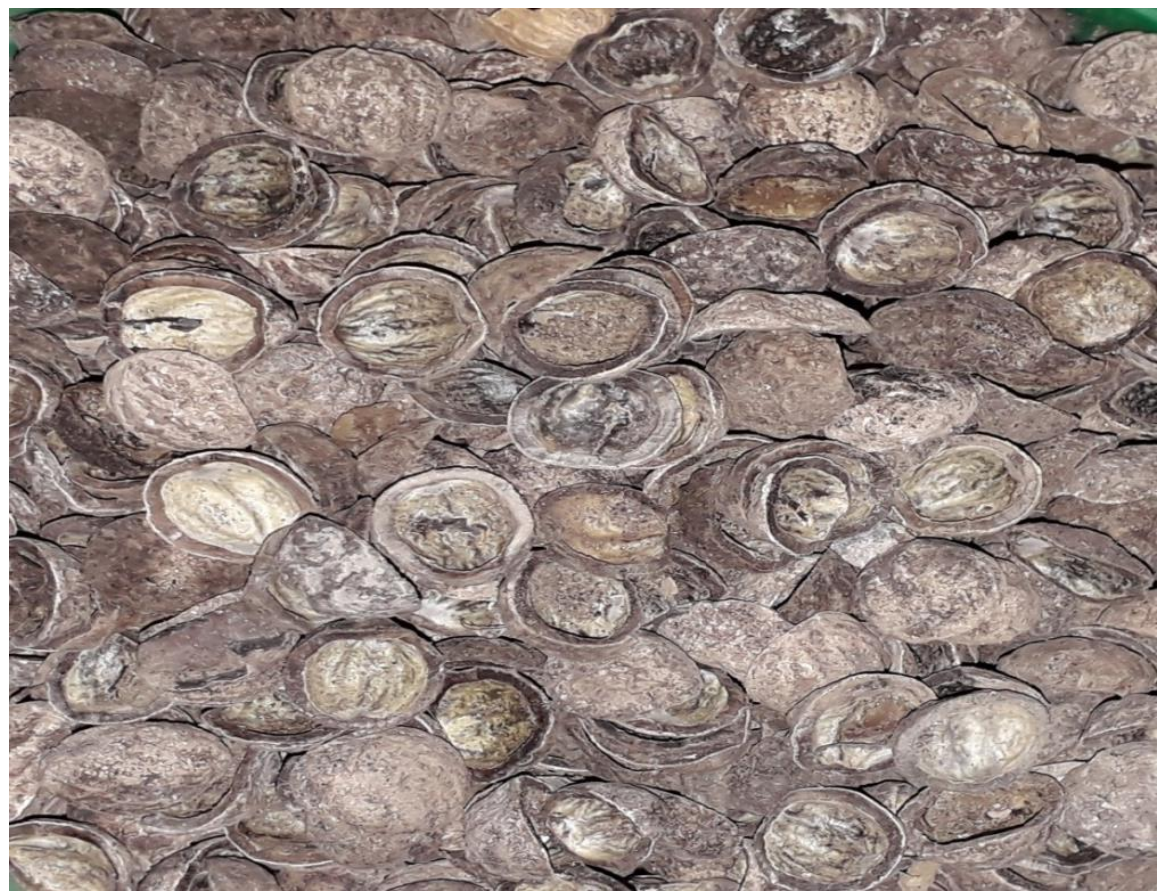

Fig. 1. Akpi nutshells (ANS).

The characteristics of the various aggregates used during this study are shown in Table 1 below.

Table 1. Characteristics of aggregates.

\begin{tabular}{lccccccccccc}
\hline Samples & $\mathbf{0 / D}$ & $\mathbf{U c}$ & $\mathbf{C c}$ & $\mathbf{F M}$ & $\begin{array}{c}\text { ESv } \\
(\boldsymbol{\%})\end{array}$ & $\begin{array}{c}\text { LA } \\
(\boldsymbol{\%})\end{array}$ & $\begin{array}{c}\text { Micro } \\
\text { Derval test } \\
(\boldsymbol{\%})\end{array}$ & $\begin{array}{c}\text { Absorption } \\
(\boldsymbol{\%})\end{array}$ & $\begin{array}{c}\text { Water } \\
\text { content } \\
(\boldsymbol{\%})\end{array}$ & $\begin{array}{c}\text { Dim } \\
(\mathbf{c m})\end{array}$ \\
\hline Gravel & $9 / 1$ & 2.3 & 1.4 & - & - & 28 & 7 & 0.36 & - & - \\
& 3 & & & & & & & & & \\
ANS & $7 / 2$ & 1.2 & 1 & - & - & 30 & 15 & 16.37 & 14.39 & 1.4 \\
& 5 & & & & & & & & & - \\
Sand & $0 / 1$ & 3 & 1 & 2.1 & 91.25 & - & - & 6.3 & - & - \\
\hline
\end{tabular}

\subsection{Formulation}

Four formulations were used in this study. The different quantities are shown in Table 2 . They were used to make cylindrical specimens of dimensions $16 \times 32 \mathrm{~cm}^{2}$ and $11 \times 22 \mathrm{~cm}^{2}$.

Table 2. Formulations of the different concrete specimens.

\begin{tabular}{ccccc}
\hline $\begin{array}{c}\text { ANS proportion } \\
(\%)\end{array}$ & $\begin{array}{c}\text { Gravel proportion } \\
(\%)\end{array}$ & Gravel / sand ratio & Water / cement ratio & Designations \\
\hline 0 & 100 & 1.9 & 0.5 & \\
\hline 5 & 95 & 1.8 & 0.5 & CG $_{100}$ ANS $_{0}$ \\
10 & 90 & 1.7 & 0.5 & CG $_{95}$ ANS $_{5}$ \\
15 & 85 & 1.6 & 0.5 & CG $_{80}$ ANS $_{10}$ \\
\hline
\end{tabular}

\subsection{Characterization of concrete}

This characterization was made in the fresh state and in the hardened state. In the fresh state, the Abrams cone subsidence test was carried out according to standard NF P18-451 [2]. In the hardened state, tests have been carried out: the ultrasonic test according to the NF P18-418 standard [3], the compression strength test on the dimension specimens of $16 \times 32 \mathrm{~cm}^{2}$ according to the NF standard P18-406 [4], and the tensile strength test by on cylindrical specimens dimension of $11 \times 22 \mathrm{~cm}^{2}$, according to standard NF P18-408 [5]. 


\section{RESULTS AND DISCUSSION}

\subsection{Workability of concrete}

The results of slump test are detailed in Figure 2.

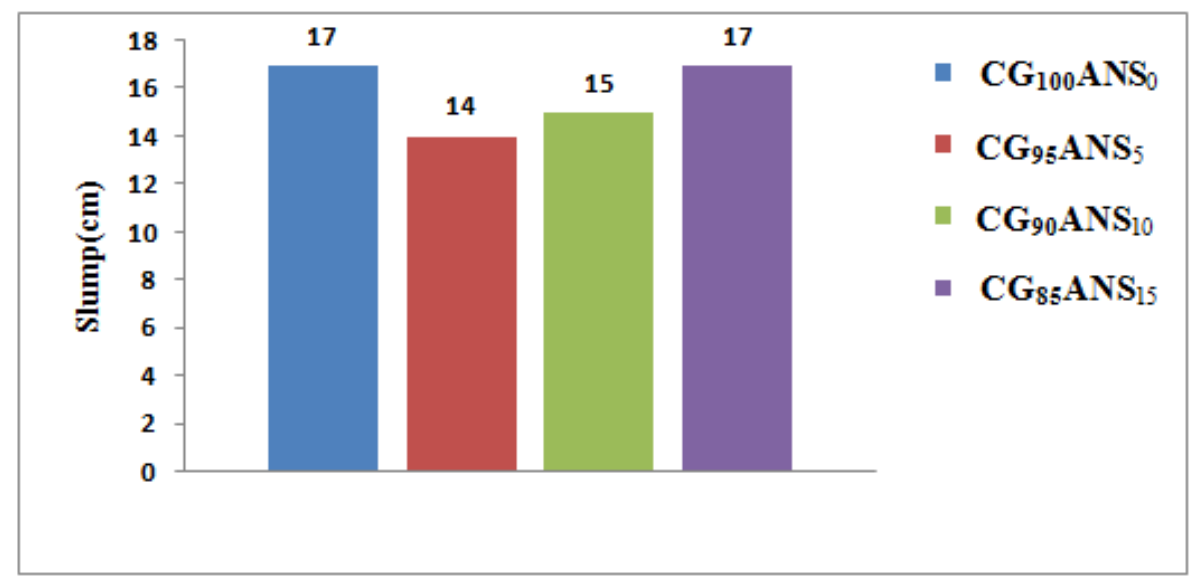

Fig. 2. Slump of the different formulation.

For a substitution rate of 5\% (CG95ANS5), the workability of concrete decreases by $18 \%$. This could be explained by an increase in the volume of water compared to the control concrete. This result is consistent with that of [1] according to which the workability of concrete decreases when natural aggregates are replaced by palm nutshell (PNS).

However, the increase in substitution up to $15 \%\left(\mathbf{C G}_{\mathbf{8 5}} \mathbf{A N S} \mathbf{N}_{\mathbf{1 5}}\right)$ leads to a return to workability. Indeed, the increase in the percentage of ANS generates that of the volume of the mix: which generates the release of the water absorbed by the hulls, the consequence of which is a return to maneuverability.

\subsection{Homogeneity}

The results obtained during the ultrasonic test are detailed in Figure 3.

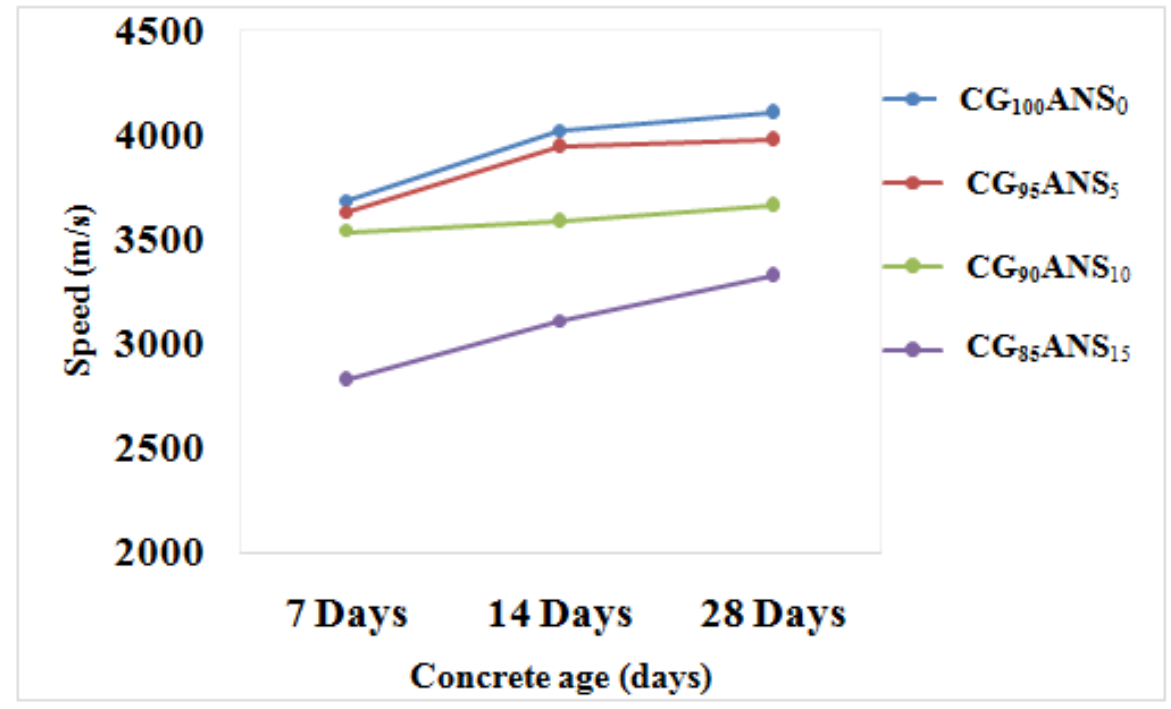

Fig. 3. Ultrasonic wave velocity curves.

Figure 3 shows that the speed of propagation of the ultrasonic waves varies inversely with the rate of substitution of the aggregates. In other words, the homogeneity of the concrete decreases when the rate of hulls increases. This would be due to bad connections between the cement paste and ANSs. This fact would cause an increasing porosity of the composite, which increases with the percentage of substitution. 
This result is confirmed by Johanesa [1] who showed that the propagation speed of ultrasonic waves decreases when the rate of ANS increases in concrete.

Furthermore, we also note that the speed of propagation of ultrasonic waves increases with the age of concrete maturation. This could be explained by the hydration reactions of the cement.

These reactions improve the homogeneity of the composite over time. In addition, for a substitution rate of 5\%, the wave propagation speed at 28 days of concrete maturation is $3978 \mathrm{~m} / \mathrm{s}$. According to [6], when the speed of propagation of ultrasonic waves is in the interval $[3500 ; 4500 \mathrm{~m} / \mathrm{s}]$, this concrete is said to be of good quality and can be used in construction. So, this formulation could be used for load-bearing structures.

\subsection{Tensile strength}

The results of the tensile strength test carried out on concrete are shown in Figure 4.

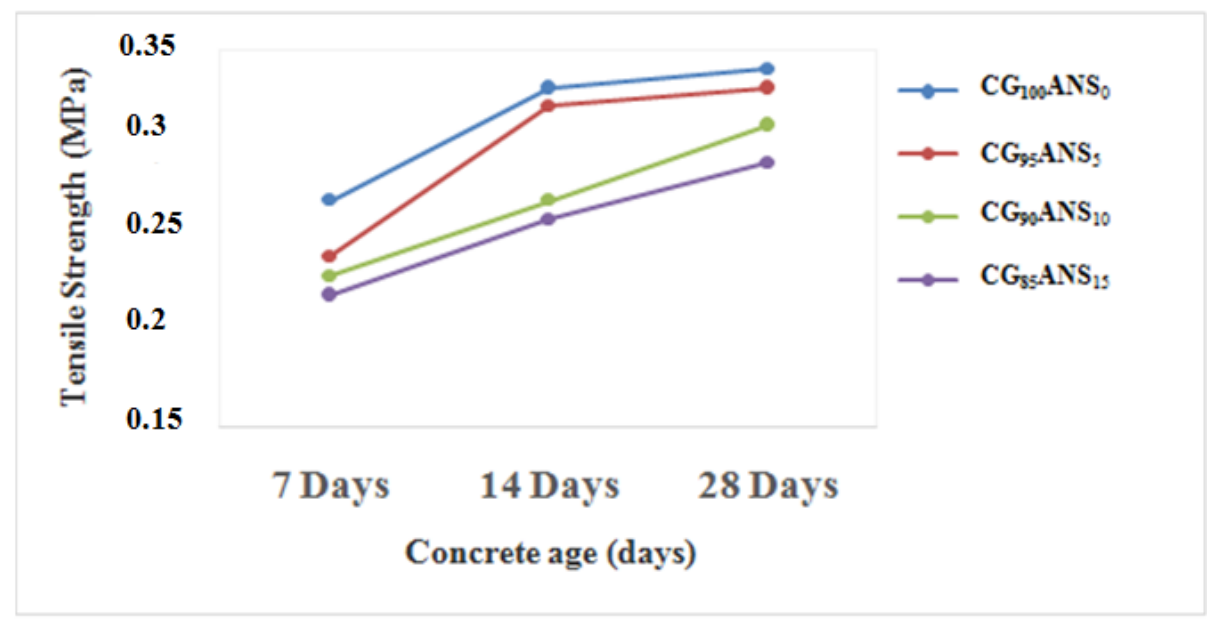

Fig. 4. Tensile strength curves.

In this figure, the tensile stress decreases with the increase in the percentage of ANS in concrete. This could be explained by poor adhesion between the ANS and the cementations paste. These results are in agreement with those of [7] who highlighted the decrease in tensile strength with the increase in the percentage of aggregates recycled in concrete. However, the tensile strength increases with the curing of the concrete, also due to the hydration reactions of the cement. Indeed, we are witnessing the formation of calcium hydrosilicates and hydroaluminates, contributing to the reduction of voids in the material.

\subsection{Compressive strength}

The results of the compressive test performed on hardened concrete are shown in Figures 5.

It appears that the compressive strength increases with the curing of the concrete. This is due to the hydration reactions of the cement which is continuous over time. They promote the crystallization of hydrosilicates and calcium hydroluminates. These gradually occupy the voids within the concrete and contribute to its densification. This result is consistent with that of [8] according to which hydration reactions improve the mechanical strength of concrete over time. Furthermore, for ANS concretes, the compressive strength changes inversely with the percentage of ANS. A lack of adhesion to the ANS interface and the cement matrix could be the cause.

In addition, there is the release of water absorbed by the ANS. Indeed, these vegetable shells have pores which contribute to the progressive reduction of the compressive strength of the concrete which contains them. This result is consistent with those of $[1,9]$ ), and [10], according to which the presence of natural shells in concrete reduces its resistance.

In addition, all ANS concretes produced have a resistance to 28 days greater than $17 \mathrm{MPa}$ : recommended value for structural construction [8]. Values that belong to the resistance classes LC 16/18 and LC 20/22. 
According to standard NF EN 206-1 [11], these concretes could be used for making light screed screeds and for filling old floors.

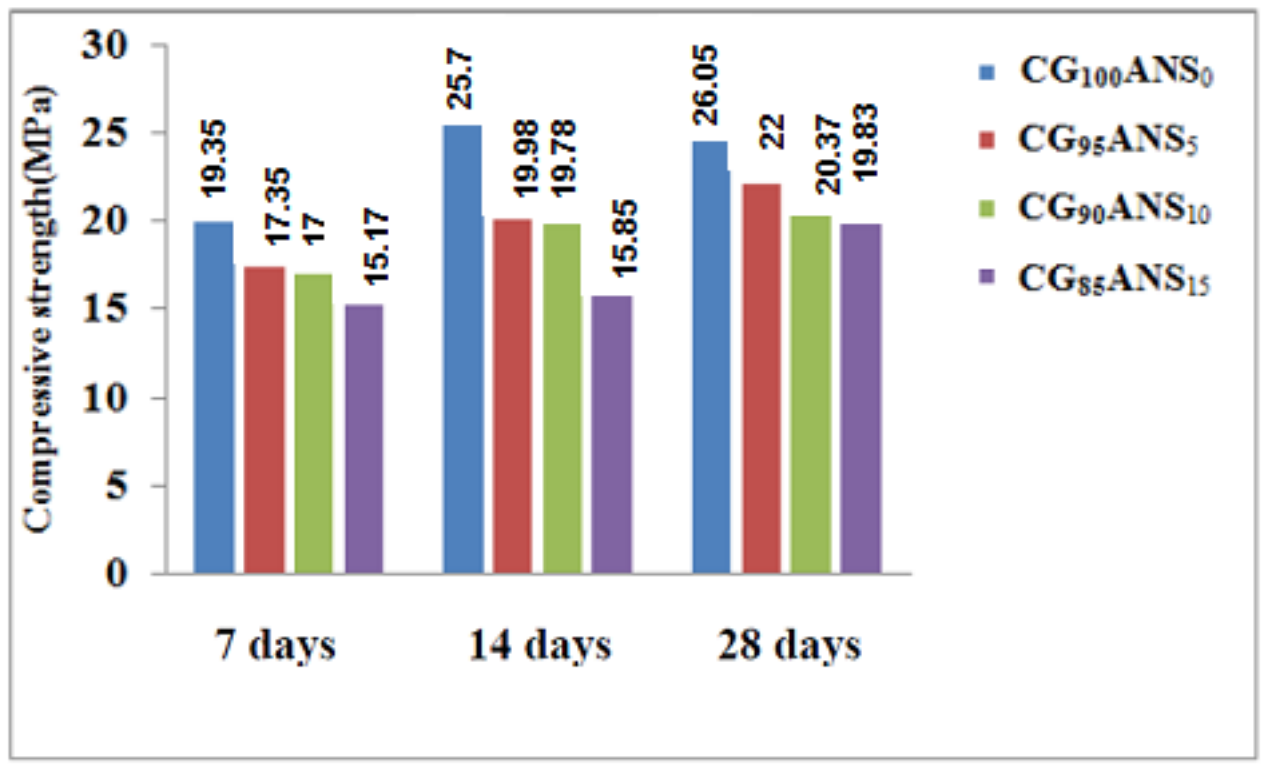

Fig. 5. Evolution of compressive strength.

Analysis of the results also shows that the growth in strength of ANS concrete is faster than that of control concrete. This result confirms that of [8] according to which the kinetics of concrete hardening is improved when it contains CNP.

In general, the compressive strengths of the control concrete remain higher than the strength of ANS concretes. This could be explained by the mechanical properties of the aggregates because the Los Angeles coefficient has shown that crushed granites are more resistant than ANS. This result agrees with the work of [8] according to which the strength of concrete decreases when it contains coconut shell.

\section{CONCLUSIONS}

In general, this study has shown that the substitution of natural aggregates by ANSs affects the physical and mechanical properties of concrete. The experimental results allowed us to draw the following conclusions:

- Substituting gravels by ANS water-saturated lowers the workability of concrete. However, beyond a certain substitution rate, the ANSs no longer influence this parameter.

- The incorporation of CNA aggregates is detrimental to the mechanical strengths of concrete. Compressive strength decreases by up to $24 \%$ for an increase in the substitution rate of up to $15 \%$. But, despite the decrease in mechanical strength, the strength of concrete at a young age is improved by up to $7 \%$.

- For a gravel substitution rate of up to $15 \%$, it is possible to obtain mechanical strengths at CNA concrete, at 28 days, greater than the $17 \mathrm{MPa}$ recommended for structural construction. These concretes could be used for making light screed and for filling old floors.

To better understand the effect of ANS on the properties of concrete, it would be interesting to:

- Carry out a study of the influence of the chemical composition of ANSs on the kinetics of concrete hardening at a young age and at maturity;

- Study the influence of the granular fraction of CNAs on the durability of concrete;

- Evaluate the effect of the ash from these shells on the physical and mechanical properties of concrete.

\section{REFERENCES}

[1] Johanesa, R.T., Comportement physico-mécanique du béton léger de coques de noix de palme: substitution, influence de la qualité de la pâte de ciment et durabilité du composite, Mémoire de Master, Institut Internationale d'Ingénierie, Burkina Faso, 2015, p. 54. 
[2] AFNOR NF P18-451, Bétons - Exécution des structures en béton - Règles spécifiques pour les BFUP, 2018, p. 1-4.

[3] AFNOR NF P18-418, Béton- Auscultation sonique. Mesure du temps de propagation d'ondes soniques dans le béton, Normalisation française, 1989, p. 1-12.

[4] AFNOR NF P18-406, Béton essai de compression. Norme française homologué, 1981, p. 1-3.

[5] AFNOR NF P18-408, Béton essai de fendage, Norme française, 1981, p. 1-7.

[6] Khodja, A.B., Corrélation entre essais non-destructifs et essais destructifs du béton à faible résistance. Mémoire de Magister, Université Hamiba Ben Bouali, Algérie, 2010, p. 1-152.

[7] Serifou, M., Béton à base de recyclâts: influence du type de recyclâts et rôle de la formulation, Thèse en cotutelle Université Félix Houphouët Boigny Abidjan-Côte d'Ivoire et Université Bordeaux 1-France, 2013 , p. $1-147$.

[8] Traore, Y., Influence du traitement des coques de noix de palme sur les propriétés physico-mécaniques des bétons légers, rapport, 33èmes Rencontres Universitaires de Génie Civil, Bayonne, 27-29 may 2015, Laboratoire Génie Civil, Université de Pau et des pays de l'Adour, France, 2015, p. 1-11.

[9] Olanipekun, E.A., Olusola, K.O., Ata, O., A comparative study of concrete properties using coconut shell and palm kernel shell as coarse aggregates, Building and Environment, vol. 41, 2006, p. 297-301.

[10] Sathiparan, N., De Zoysa, H.T.S.M., The effects of using agricultural waste as partial substitute for sand in cement blocks, Journal of Building Engineering, vol. 19, 2018, p. 216-227.

[11] AFNOR NF EN 206-1, Béton-Partie 1: Spécification, performances, production et conformité, 2004, p. 110. 